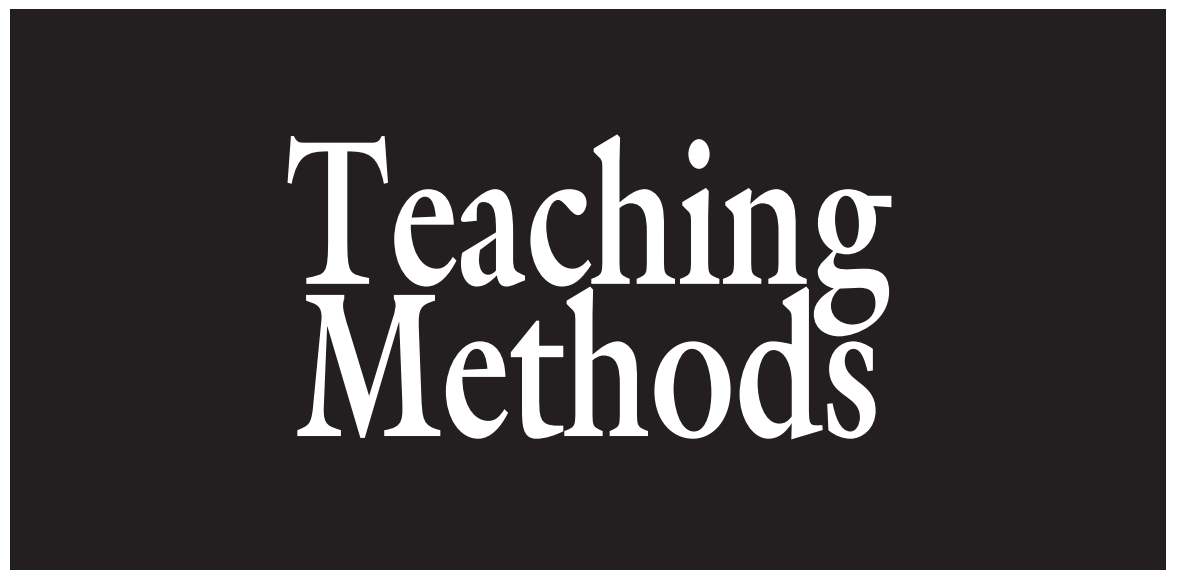

\section{An Economic Analysis of a University Educational Cafeteria Composting Program-Bobcat Blend}

\author{
Jason Sanders ${ }^{1}$, Tina Marie Waliczek ${ }^{2,4}$, and Jean-Marc Gandonou ${ }^{3}$
}

ADDITIONAL INDEX wORDs. food waste, feedstocks, recycling, sustainability, waste audit, source separation, pre consumer food residual, post consumer food residual

Summary. At Texas State University, a cafeteria-composting pilot program was established in which students source-separated their organic waste at one of the food courts while the program educated students on the value of organic waste and compost. Waste sorting bins were set up in a dining hall to direct students to sort trash into recyclables, compostables, and trash. Waste audit results demonstrated the value of the operation to the university in terms of savings in waste hauling expenditures, as well as showed the percent contamination, and percent waste diverted to the university's recycling and composting program. There was a significant difference between pre and post-test waste audits. The pilot site composting program resulted in a net loss of $\$ 3741.35$ to the university during the first year, but was expected to produce a positive net return of $\$ 2585.11$ in subsequent years. The pilot test showed the program was most successful when ongoing education at the dining hall occurred. Additionally, the student-run composting program resulted in hands-on training for students in producing a valuable horticultural commodity in an emerging waste management field. Results also indicated opportunities for further diversion such as the incorporation of compostable cups and utensils, as well as through expanding the operation to include more collection locations. With more collection sites and, therefore, more efficiency, the expanded composting program has the potential to become a self-supporting operation.

$\mathrm{T}$ he U.S. Environmental Protection Agency (EPA) reported organic materials including yard trimmings, food scraps, wood waste, and paper products represented the largest component of the U.S. municipal solid waste (MSW) stream (EPA, 2010a). These organic materials make up more than two-thirds of the total

${ }^{1}$ Graduate Assistant, Department of Agriculture, Texas State University, San Marcos, TX 78666

${ }^{2}$ Professor, Department of Agriculture, Texas State University, San Marcos, TX 78666

${ }^{3}$ Assistant Professor, Department of Agriculture, Texas State University, San Marcos, TX 78666

${ }^{4}$ Corresponding author. E-mail: tc10@txstate.edu.
249.6 million tons of MSW generated in 2008 (EPA, 2010a). Food scraps alone represented $12.7 \%$ of the MSW generated in 2008 and included uneaten food and food preparation scraps from residences or households and commercial establishments such as restaurants, grocery stores, and cafeterias (EPA, 2010a).

A total of 356 billion pounds of edible food (fresh and processed) was produced in 1995, 27\% (96 billion pounds) of which was wasted by retailers, foodservice providers, and consumers (Kantor et al., 1997). The total cost of disposing this food waste in the United States was over \$1 billion (EPA and U.S. Department of Agriculture, 2011).

There is an environmental problem associated with food waste. Only $3 \%$ of the total food scraps were reused or recycled and the remaining 31 million tons ended up in landfills or incinerators (EPA and U.S. Department of Agriculture, 2011). When these organics are disposed in landfills, after one to two years, anaerobic decomposition occurs creating methane, a greenhouse gas 21 times stronger in trapping heat within the atmosphere than carbon dioxide (EPA, $2010 \mathrm{~b}$ ). Landfills account for $22 \%$ of the total U.S. anthropogenic methane and are the second largest source of all methane production in the United States (EPA, 2010b).

The United States has $\approx 1800$ operating landfills (EPA, 2010b). In Texas, there are 280 permitted landfills with an average disposal cost of $\$ 27.80$ per ton (Texas Commission for Environmental Quality, 2009). A total of 33.08 million tons of MSW was disposed in Texas, equaling a per capita rate of $7.4 \mathrm{lb}$ per person per day (Texas Commission for Environmental Quality, 2009). With this rate of disposal, Texas landfills have a remaining capacity of 44 years (Texas

\begin{tabular}{llll}
\hline $\begin{array}{l}\text { Units } \\
\begin{array}{l}\text { To convert U.S. to SI, } \\
\text { multiply by }\end{array}\end{array}$ & U.S. unit & SI unit & $\begin{array}{l}\text { To convert SI to U.S., } \\
\text { multiply by }\end{array}$ \\
\hline 0.4047 & acre $(\mathrm{s})$ & $\mathrm{ha}$ & 2.4711 \\
0.3048 & $\mathrm{ft}$ & $\mathrm{m}$ & 3.2808 \\
3.7854 & gal & $\mathrm{L}$ & 0.2642 \\
0.7457 & horsepower & $\mathrm{kW}$ & 1.3410 \\
25.4 & inch(es) & $\mathrm{mm}$ & 0.0394 \\
0.4536 & lb & $\mathrm{kg}$ & 2.2046 \\
1.6093 & mile $(\mathrm{s})$ & $\mathrm{km}$ & 0.6214 \\
1 & mmho/cm & $\mathrm{dS} \cdot \mathrm{m}^{-1}$ & 1 \\
1 & ppm & $\mathrm{mg} \cdot \mathrm{kg}^{-1}$ & 1 \\
0.9072 & ton $(\mathrm{s})$ & $\mathrm{Mg}^{3}$ & 1.1023 \\
0.7646 & yard & $\mathrm{m}$ & 1.3080
\end{tabular}


Commission for Environmental Quality, 2009). Diverting organic waste to processing facilities, such as composting facilities, will increase the life expectancy of landfills (Beck, 2009).

Currently in the state of Texas, there is no disposal ban for organics in landfills, and this lack of regulation can explain the low diversion rates of organic waste (Beck, 2009). However, communities do have the power to enact disposal bans through contracts with their local trash haulers. One example of this is the City of Arlington's (Texas) “Don't Bag It" program, which does not allow the hauler to collect lawn waste (Beck, 2009). Another example of local action is City of McAllen providing a $50 \%$ discount to commercial businesses that divert organic waste to their composting facility (Beck, 2009).

Composting facilities generally have two different types of markets for compost: dollar markets and value markets (Tyler, 1996). Dollar markets are markets that have the ability to offer the highest price for compost at the lowest volume. These markets generally consist of retail garden centers and nurseries centrally located within a city (Tyler, 1996). Value markets are high volume markets paying a low price per cubic yard. These markets are generally focused on those for agricultural use and/or sod markets (Tyler, 1996).

The U.S. compost market is a relatively large market. Research has estimated the compost market value at 518 million tons annually (Shiralipour et al., 1992). The majority of the revenue was generated in the dollar markets and the majority of the volume used was represented in the value markets (Slivka et al., 1992; Tyler, 1996; EPA, 1993). The average cost of compost in the retail markets/ garden centers was $\$ 16$ to $\$ 25$ per cubic yard with an estimated available market of 4.4 million tons, while the average cost of compost in the agricultural market is $\$ 0$ to $\$ 2$ per cubic yard with an estimated available market of 445 million tons (Tyler, 1993). Malcolm Beck has pioneered the compost markets in Texas. His sales consisted mainly in dollar markets with $40 \%$ of sales being retail and $60 \%$ of sales being wholesale (Goldstein, 1993).

Colleges and universities are well-equipped with the knowledge and resources to provide leadership and develop models to approach the environmental challenges surrounding waste management as well as promote change through the education of citizens (Leal Filho et al., 1996). Colleges and universities around the nation are developing and implementing environmental programs which include landscaping, food service, transportation, and waste management to increase campus environmental stewardship (Mansfield III, 1998). To take a step further, these environmental programs provided the opportunity for new, innovative hands-on learning experiences rather than traditional textbook and lecture learning (Mansfield III, 1998).

By creating more sustainable campus practices, academic institutions can demonstrate to students the importance of environmental stewardship so they can bring these lessons to others outside of the campus community (Creighton, 1999). Sustainability is defined "as meeting the needs of the present without compromising the ability of future generations to meet their own needs" (United Nations, 1987). To reach the goals of a sustainable campus, we must act on "closing the loop...to become a self contained facility that grows its own food, generates its own electricity, and recycles its own waste" (Orr, 1989).

Ithaca College has a cafeteriacomposting program that composts 5 tons of food waste per week, which accounts for $15 \%$ of its total waste stream (Bonhotal and Rollo, 1996). This diversion of organic waste results in an annual cost saving of $\$ 8000$ to the school (Bonhotal and Rollo, 1996). Middlebury College in Vermont composted a total of 252.7 tons of food and paper waste in 1995 bringing a cost savings of more than $\$ 25,000$ back to the college (Bonhotal and Rollo, 1996). It is estimated that Texas State University's cafeteria disposes a staggering 9 tons of food waste monthly (L. Bulkley, personal communication). This amount of waste going to the landfill could possibly bring a cost savings to the university if diverted to a composting facility. The purpose of this study was to develop a university campus student sourceseparation composting program to evaluate the cost effectiveness of the operation while raising student awareness of compost as an agricultural/ horticultural commodity.

\section{Materials and methods}

UnIVERSITY SITE. The study took place at Texas State University in San Marcos, TX. The overall student enrollment is $\approx 32,000$. The main campus has 225 buildings with construction occurring in recent years to accommodate the growing enrollment. The campus includes six dining hall establishments.

RESEARCH SITE DINING HALl. The primary research site for this study was the student center dining area which included a food court with the following choices of establishments: Starbucks (Seattle, WA), Chick-fil-A (Atlanta, GA), Pizza Hut (Dallas, TX), and Blimpie (Atlanta, GA) among others. Foods are packaged in paper, plastic, cardboard, or polystyrene. This site was chosen for its accessibility to the general student, faculty, and staff population. It is considered the main student center on campus, and it supports many university events including freshman orientation.

Development of THE STUDENT SOURCE-SEPARATION AREA. The first step taken to implement the cafeteria composting program was to meet with the stakeholders affiliated with the student center food court. These stakeholders included decision makers from the campus's food service provider and the university student center officials. Together, decisions were made regarding the number of collection containers, pick-up times, and impact on staff. Food and recycling sorting sites were chosen in the food court based on the proximity of the existing trashcans, space availability, and ease of access for those eating at the dining center. Food and recycling pick-up sites at the back loading dock were chosen for areas that would cause the least interference with the loading bays, proximity to the 30 -yard $\mathrm{d}^{3}$ trash compactor, and ease of access for the food court staff and the student coordinators.

It was determined that funding was needed to purchase 11 threecompartment source-separating bins, as well as a utility trailer, and to hire one graduate student coordinator, and one student worker. OTTO Environmental Systems (Charlotte, NC) donated ten 95-gal carts for collections.

Pre versus post-waste audit. A pre-test vs. post-test research design 
was used to compare results of two waste audits between Spring 2009 and Spring 2010. Before starting the collections of the organic material, a pretest waste audit was performed to assess the volumes and characteristics of the waste generated at the student center food court. Waste audits occurred during midweek because students typically attend classes and come to campus more vigilantly during midweek. The waste audit procedures were known to be a reliable and valid technique to measure waste (Mohee, 2004; Dowie et al., 1998) and researchers adhered closely to guidelines in the Resource Recovery Fund Board's Waste Audit Guide (Resource Recovery Board Inc., 2010).

One week before each waste audit, a letter was distributed to the food service personnel who informed their staff of the scheduled waste audit. On the morning of each waste audit, a poster board notification sign was placed on the door of the trash compacter informing the food court staff that all trash bags should be placed in the designated waste audit bins. These bins were lined up along the walkway toward the trash compactor in high visibility areas. A student coordinator stayed on the back dock throughout the day monitoring the bags being placed into the waste audit bins to assure all trash bags were being included in the study.

Periodically throughout the day, the student coordinators would empty the bags from the waste audit containers into a utility trailer. The bags were transported to the waste sorting area, where they were opened and sorted into the designated categories labeled on 44-gal containers. Categories included liquids (liquids from beverage cups and food matter), post consumer food waste (uneaten food including meats, bones, and any solid dairy products), food containers (plastic food containers), plastic bottles (all plastic bottles labeled \#1-\#7), trash (non-recyclable and compostable items), beverage cups (fountain drink cups), polystyrene number 6 (all polystyrene service items), glass (all glass containers), cans (all aluminum cans), liners (all trash liners), and non-recyclable paper (any paper that was food-spoiled, yet compostable).

Final weights and volumes of waste from the student center within the categories were entered into PASW (version 17.0; IBM, Somers, NY). Descriptive statistics were used to determine means per categories and a Wilcoxon signed rank test compared means of total weights and volumes.

Educating STUdents ON THE COMPOSTING PROCESS. Students in the student center dining area were educated before and during the program implementation. Pre-education took place by setting up table tent flyers in the dining area 2 weeks before program implementation. These flyers informed the students of the upcoming composting program. The table tent flyers stated the program's objectives, the purpose of the program, and instructions on what items went into each bin. Contact information for any questions, comments, or concerns was also posted.

A logo donated by the university marketing team was created for the Bobcat Blend composting program, to provide brand identification and education on composting to the student body. The educational signage for the source-separation bins was created and donated by the student center's marketing team and was designed with pictures of the exact food and beverage items sold in the food court, so participants would clearly understand into which bin each item was to be disposed. There were a total of three signs created: organic waste, bottles and cans, and trash. These signs were placed in highly visible locations directly above the containers. An art student for a class project created the Bobcat Blend educational poster. The poster was a black and white and illustrated the purpose of the program, along with the acceptable and non-acceptable compostable items.

During the peak dining hours for the first 2 weeks of each semester, the graduate student coordinator and a student worker stood by the sourceseparation bins educating students on what items went into each bin as well as the purpose and benefits of the program.

Composting site. Processing of organic residuals took place 10 miles off campus at the Texas State University Muller Farm. This site was previously used as an alternate grazing source for the livestock kept at Texas State University Freeman Ranch. Muller Farm is $\approx 125$ acres and 5 acres was allocated for the compost site. Funding for construction of the compost site was obtained through a grant for another composting project. Of the 5 acres allocated for the compost site, 2.285 acres was transformed into a catchment pond that could withstand a 25 years $/ 24$-h-rain event. The remaining 2.715 acres was cleared and graded so the retention pond would capture any water runoff from the compost piles. Fences and gates were also installed to keep out any livestock and to contain feedstocks used for composting.

Composting Process. The compost piles were created using 25\% food residuals from the student center and $75 \%$ wood waste donated by a local tree company. This mix was blended using a skid steer with a $1 / 3$ yard $^{3}$ bucket. The piles were turned four times annually and watered with the captured water from the collection pond on each turn.

Compost QUALITY TeSTS. A 5-gal sample of the finished compost drawn from various depths within the compost piles was sent to the Agricultural Analytical Services Laboratory (University Park, PA), a Seal of Testing Approved compost quality testing laboratory. The laboratory performed the following tests on the compost sample: percent solids, organic matter, $\mathrm{pH}$, soluble salts, total nitrogen, total carbon, carbon/nitrogen ratio, ammonium nitrogen, phosphorus, potassium, calcium, magnesium, arsenic, cadmium, copper, lead, mercury, molybdenum, nickel, selenium, zinc, respirometry test, bioassay, and particle size $(<9.5 \mathrm{~mm})$.

ECONOMIC DATA. Economic data were collected to assess the cost as well as the savings associated with the program. Related costs included include start-up, disposal, educational, collection, transportation, and processing costs.

The start-up costs for the composting program were a one-time cost covered through grant money and donations. These included the cost of the indoor source-separation bins, exterior collection bins, 16-ft utility trailer, educational signs and posters, and the logo design. The life expectancy of the indoor source-separation bins, the exterior bins, and the $16-\mathrm{ft}$ utility trailer were estimated at 15, 7 , and 10 years, respectively. The educational signs and the posters were donated by the student center administration and the logo is expected to be used in the foreseeable future as part of the program. 
The trash disposal costs were associated with the student center's trash compactor and were obtained from Texas State University's records. The 30-yard ${ }^{3}$ trash compactor has a compaction rate of 3 to 1 , so the total capacity is estimated at $90 \mathrm{yard}^{3}$. It is pulled when the compaction rate is maxed, which is read by a meter con$\mathrm{arm}$. The trash compactor had a monthly rental and pull fee of $\$ 6494.04$ during the study period (Table 1). The rental fee increased by $5 \%$ every year since 2008 while the pull fee decreased. The compactor cost for the post study years was extrapolated using the past year's cost (Table 1). The compactor cost saving accredited to the collection was $\$ 198.83$. It was obtained by subtracting the compactor cost incurred by the university before the study period from that incurred during the study period. This saving is expected to increase to $\$ 302.46$ in subsequent years (Table 1).

The costs associated with the educational program (Table 2 ) were primarily students' labor costs. Student trolled by the hydraulic compaction

workers stationed outside the sorting bins of the cafeteria demonstrated the proper sorting procedure to students. The educational labor cost during the study period was based on one student working $2 \mathrm{~h}$ per day, $3 \mathrm{~d}$ per week, for 36 weeks at $\$ 8.00 / \mathrm{h}$ (Table 2$)$. For the subsequent years, the educational costs included one student worker for $2 \mathrm{~h}$ per day, $3 \mathrm{~d}$ per week, for 8 weeks. It is expected less educational time will be required after the program has been established.

The transportation costs included labor for hauling both the wood waste needed for composting and the cafeteria food residuals to the compost site. The transportation costs during the study period for the wood waste included the cost of one student worker for $1 \mathrm{~h}$ per haul and 30 total hauls at $\$ 8.00 / \mathrm{h}$. For the subsequent year, the transportation cost is expected to remain the same (one student worker for $1 \mathrm{~h}$ per haul and 30 total hauls at $\$ 8.00 / \mathrm{h}$ ) (Table 2).

Labor costs for the hauling of the student center's organic residuals during the study period included one

Table 1. Trash container rental and disposal costs, and savings of the university student center's trash compactor before and during implementation, and predicted costs and savings during subsequent years of the university educational cafeteria-composting program at Texas State University, San Marcos.

\begin{tabular}{lrcc}
\hline Time period & $\begin{array}{c}\text { Pre-study } \\
\text { time }^{\text {period }}\end{array}$ & $\begin{array}{c}\text { Study time } \\
\text { period }^{\mathrm{y}}\end{array}$ & $\begin{array}{c}\text { Subsequent } \\
\text { years }^{\mathbf{x}}\end{array}$ \\
\hline $\begin{array}{l}\text { Rental cost } \\
\text { Pull cost }\end{array}$ & $\$ 3,239.10$ & $\$ 3,401.05$ & $\$ 3,658.20$ \\
Total cost & $\$ 6,854.82$ & $\$ 6,494.04$ & $\$ 6,133.26$ \\
Savings & $\$ 10,093.92$ & $\$ 9,895.09$ & $\$ 9,791.46$ \\
\hline
\end{tabular}

${ }^{2}$ Pre-study time period represents the dates of Aug. 2008 to May 2009.

'Study time period represents the dates of Aug. 2009 to May 2010.

${ }^{x}$ Subsequent years represent the estimated costs and savings for the dates of Aug. 2010 to May 2011. student worker for $0.5 \mathrm{~h}$ per haul twice per week for 36 weeks at $\$ 8.00 / \mathrm{h}$. To make predictions of costs and savings for subsequent years, the labor cost for hauling organic residuals was calculated with the same figures used during the study period.

The ownership costs for the transportation vehicle were assessed and included depreciation, financing, fuel, maintenance, and repairs (Table 3 ). The total cost for transporting the material was estimated to represent $20 \%$ of the ownership costs for a 2007 Toyota Tacoma valued at $\$ 958.00$ (Interlink Media, 2010) (Table 3). The vehicle's expected use for the project was 2000 miles per year, which was $20 \%$ of the annual use.

The processing costs of the compost included the variable costs of labor for turning the piles and screening the material. No grinding costs were associated with the program because the wood waste was pre-ground by the tree company. The operating and ownership costs included processing the material with the 40-horsepower skid steer with a $1 / 3$-yard ${ }^{3}$ bucket (Table 3 ) (Rynk, 1992). The screener had a 1.5horsepower engine with an output of $1.10 \mathrm{~kW}$. The cost for screening the material was based on the city's average electricity cost of $\$ 0.095$ per $\mathrm{kWh}$. The life expectancy of the screener motor was estimated at 5 years; therefore, depreciation costs of $\$ 50.00$ per year were applied (Table 3 ). No taxes were included for the land because the university is a tax-free entity.

The total program cost for the program was calculated for the time period during the study as well as those subsequent years after the study. The

Table 2. Educational, transportation, and processing costs of compostable materials during implementation of the university educational cafeteria-composting program at Texas State University, San Marcos.

\begin{tabular}{|c|c|c|c|c|c|}
\hline Cost category & Unit cost & Unit & $\begin{array}{c}\text { Cost } \\
\text { per unit }\end{array}$ & Units (no.) & $\begin{array}{c}\text { Total } \\
\text { variable costs }\end{array}$ \\
\hline Education & Labor-student worker number 1 & Hour & $\$ 8.00$ & 216.00 & $\$ 1,728.00$ \\
\hline \multirow[t]{2}{*}{ Transportation } & Student center-labor student worker number 1 & Hour & $\$ 8.00$ & 36.00 & $\$ 288.00$ \\
\hline & Student center-labor-student worker number 2 & Hour & $\$ 8.00$ & 36.00 & $\$ 288.00$ \\
\hline \multirow[t]{4}{*}{ Processing } & Turning the piles & Cubic yard ${ }^{\mathbf{z}}$ & $\$ 1.42$ & 304.00 & $\$ 431.68$ \\
\hline & Screening-labor-student worker number 1 & Hour & $\$ 8.00$ & 20.00 & $\$ 160.00$ \\
\hline & Screener-labor-student worker number 2 & Hour & $\$ 8.00$ & 20.00 & $\$ 160.00$ \\
\hline & Screening-electricity & Kilowatt hour & $\$ 0.095$ & 20.00 & $\$ 1.90$ \\
\hline
\end{tabular}

${ }^{\mathrm{z}} 1 \operatorname{yard}^{3}=0.7646 \mathrm{~m}^{3}$. 
Table 3. Fixed, variable, first year total and predicted subsequent year total costs associated with the education of student workers, transportation, and processing of the compostable materials during the implementation of the university educational composting program at Texas State University, San Marcos.

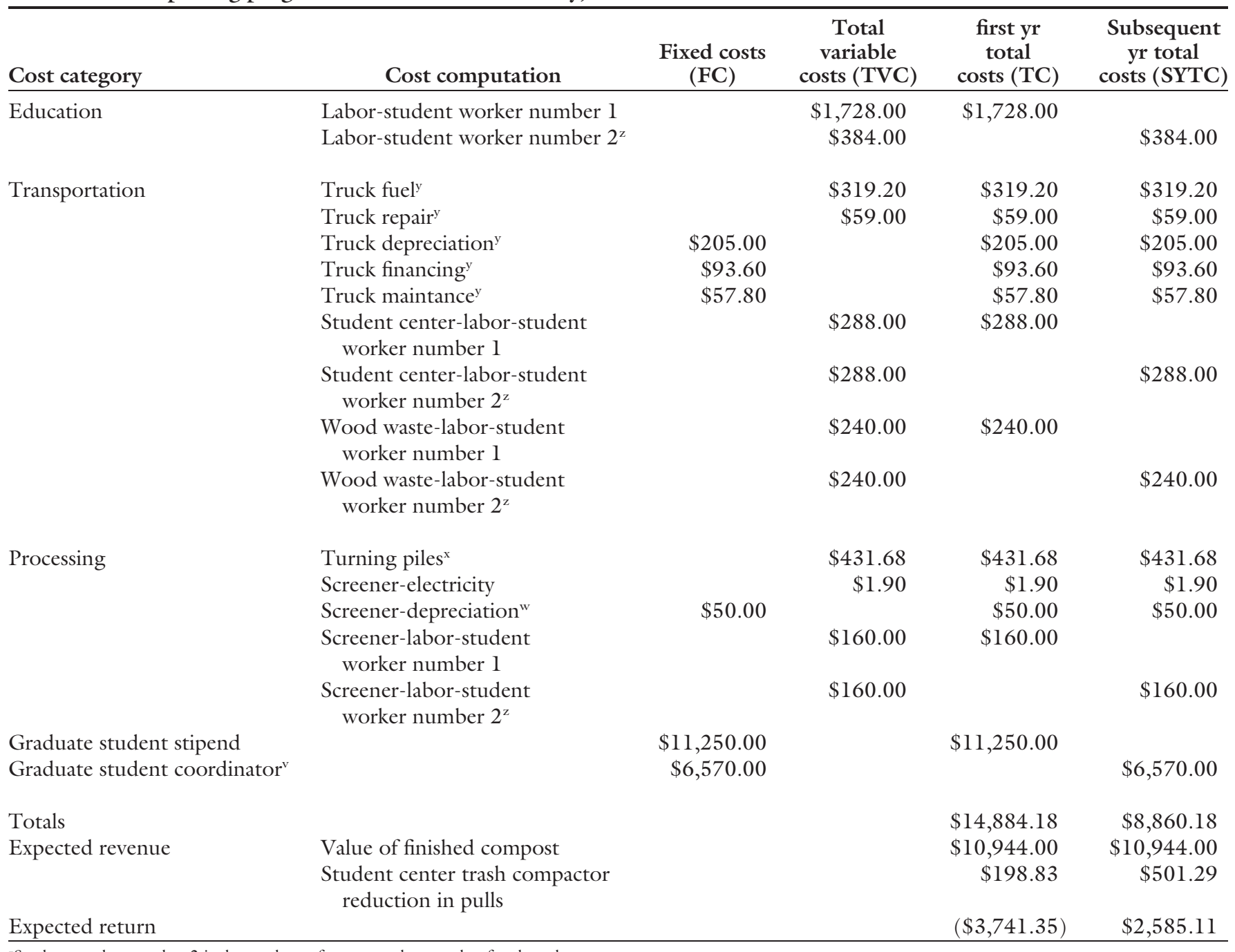

${ }^{\mathrm{z}}$ Student worker number 2 is the total cost for one student worker for the subsequent years.

y Ownership cost on vehicle was obtained from the Internet Auto Guide (Interlink Media, 2010) for the third year; $20 \%$ of the total cost was used.

${ }^{x}$ Data on cost on turning piles was obtained from Rynk (1992). These costs included all operating and ownership costs.

wDepreciation is applied annually to a 1.5 -horsepower $(1.12 \mathrm{~kW})$ electric motor with a life expectancy of 5 years.

'Graduate student coordinator's cost for the subsequent year is valued at $50 \%$ of the total graduate's stipend of $\$ 1095.00$ due to the use of only 10 h of labor per week.

total cost of the graduate student coordinator during the study period included the time allocated in starting up the program including educational programming labor, transportation time, processing labor, and research time. Responsibilities will be less in the years following the study since the graduate student coordinator will only oversee the transportation and processing of materials and help with the program education. Therefore, for the subsequent years, $50 \%$ of original costs of the graduate research coordinator were used in calculations (Table 3 ).

\section{Results and discussion}

COMPOST PRODUCTION AND QUALITY. The total volume of finished compost for the year's production was estimated at 304 yard $^{3}$. The dollar market value of $\$ 36.99 /$ yard $^{3}$ was determined from a local retail supplier (G. Frank, personal communication) (Table 3). Results of the compost quality tests showed the quality of compost created from student center dining hall residuals was in the acceptable ranges given industry quality standards with the exception of moisture (low), solids (high), and carbon (low) content (Table 4). Researchers believe these less than ideal values on these variables may have been partially due to the inexperienced student equipment operators who inadvertently mixed in compost pad surfaces while turning compost piles at the beginning of the study. With more experienced operators and improvements to the compost pad surface in the future, it is hoped these problems will be alleviated.

STUdent Center education. The education process in the student center took longer than expected. Originally, the graduate research student and the student coordinator were planning to spend the first 2 weeks of each semester during the peak dining hours of 11:00 AM to 2:00 PM in the dining center helping direct students, faculty, and staff in the sorting process. Because of the number of student diners and the lack of knowledge about recycling among the student body, the graduate research student 
Table 4. Finished compost quality laboratory test results from compost created from post consumer food waste in an economic analysis of a university educational cafeteria-composting program at Texas State University, San Marcos. $^{\text {z }}$

\begin{tabular}{|c|c|c|c|}
\hline Variable of interest $\mathrm{t}^{\mathrm{y}}$ & $\begin{array}{c}\text { Results } \\
\text { (as is basis) }\end{array}$ & $\begin{array}{c}\text { Results } \\
\text { (dry wt basis) }\end{array}$ & Normal range \\
\hline $\mathrm{pH}$ & 7.80 & $\mathrm{n} / \mathrm{a}^{\mathrm{x}}$ & $5.00-8.00$ \\
\hline $\begin{array}{l}\text { Soluble salts }(1: 5 \mathrm{wt} / \mathrm{wt}) \\
\quad(\mathrm{mmho} / \mathrm{cm})\end{array}$ & 1.53 & $\mathrm{n} / \mathrm{a}$ & $1.00-10.00$ \\
\hline Solids $(\%)$ & 75.70 & $\mathrm{n} / \mathrm{a}$ & $50.00-60.00$ \\
\hline Moisture (\%) & 24.30 & $\mathrm{n} / \mathrm{a}$ & $40.00-50.00$ \\
\hline Organic matter (\%) & 34.50 & 45.60 & $30.00-70.00$ (dry wt) \\
\hline Total nitrogen $(\%)$ & 0.90 & 1.20 & $0.50-2.50($ dry wt $)$ \\
\hline Organic nitrogen $(\%)$ & 0.90 & 1.20 & $0.50-2.50$ (dry wt) \\
\hline Ammonium nitrogen $\left(\mathrm{mg} \cdot \mathrm{kg}^{-1}\right)$ & 16.50 & 21.70 & 0.50 \\
\hline Carbon $(\%)$ & 17.90 & 23.60 & $<54.00$ \\
\hline Carbon:nitrogen ratio & 19.40 & 19.40 & $<20.00($ dry wt) \\
\hline Phosphorus (\%) & 0.54 & 0.72 & $\mathrm{n} / \mathrm{a}$ \\
\hline Potassium (\%) & 0.49 & 0.64 & $\mathrm{n} / \mathrm{a}$ \\
\hline Calcium (\%) & 10.04 & 13.28 & $\mathrm{n} / \mathrm{a}$ \\
\hline Magnesium (\%) & 0.28 & 0.37 & $\mathrm{n} / \mathrm{a}$ \\
\hline Particle size $<9.5 \mathrm{~mm}(\%)$ & 99.67 & $\mathrm{n} / \mathrm{a}$ & $\mathrm{n} / \mathrm{a}$ \\
\hline $\begin{array}{l}\text { Stability-emergence } \\
\quad(\% \text { of control })\end{array}$ & 100.00 & $\mathrm{n} / \mathrm{a}$ & $\begin{array}{c}\text { Very mature }>90.00 \\
\text { Mature } 80.00-90.00 \\
\text { Immature }<80.00\end{array}$ \\
\hline $\begin{array}{l}\text { Stability-seedling vigor } \\
\quad(\% \text { of control })\end{array}$ & 100.00 & $\mathrm{n} / \mathrm{a}$ & $\begin{array}{c}\text { Very mature }>95.00 \\
\text { Mature } 85.00-95.00 \\
\text { Immature }<85.00 \\
\end{array}$ \\
\hline
\end{tabular}

${ }^{\mathrm{z} C o m p o s t}$ quality test results were obtained from Agricultural Analytical Services Laboratory (University Park, PA), a Seal of Testing Approved compost quality testing laboratory using the Test methods for the examination of composting and compost (U.S. Composting Council, 2002).

${ }^{\mathrm{y}} 1 \mathrm{mmho} / \mathrm{cm}=1 \mathrm{dS} \cdot \mathrm{m}^{-1}, 1 \mathrm{mg} \cdot \mathrm{kg}^{-1}=1 \mathrm{ppm}, 1 \mathrm{~mm}=0.0394$ inch

${ }^{x}$ Not applicable.

and the student coordinator spent $2 \mathrm{~h}$ per day, $3 \mathrm{~d}$ per week for the entire 36 weeks of the two semesters helping direct students through the sorting process. This extra time allotted for education proved to be helpful in increasing awareness of the program, increasing diversion rates, and reducing contamination within the bins.

To increase awareness of the graduate research coordinator and the student worker as part of the Bobcat Blend composting project, both students wore referee jerseys while in the student center during educational efforts. These jerseys increased the visibility and recognition of the student educators and the Bobcat Blend project in the student center. Student volunteers for the project also helped coach students through the sorting process and educate diners on the purpose of the project during peak hours in the dining center. Volunteers were contacted and recruited through student organizations, as well as by instructors in classrooms.

Presentations were also given to various student organizations which helped better inform and educate students about the program and its purpose. The Associated Student Government on campus passed legislation that expressed their support of the composting program, which helped increase support from the school's administrators, faculty and staff, and the food service providers.

Researchers found the original signage above the sorting bins which labeled compostables as "organic waste" confused the student body due to their lack of understanding of the term "organic." Students originally thought only organically grown food could be placed in the "organic waste" bin. This was corrected by having one sign labeled as "food" and another as "paper." The bin signs were then changed to become a three-bin system labeled as "food," "bottles and cans," and "paper," and they were referred to as "eco-stations." All of the pre-existing trash cans were brought back into the student center and labeled "trash." All educational signs still included exact pictures of each of the items designated for disposal within each bin. When sorting bins included a trash slot, the trash bins filled up faster than the other compartments, which called for more exchanges by the custodial staff. This increased their labor with the program in place. Labeling the trash cans and increasing the number of trash cans helped accommodate the high volume of trash materials.

The graduate research coordinator and the student worker also noticed beverage cups were continuously placed in the "paper" compartment. However, beverage cups included a polyethylene liner and could not be composted. To reduce this contamination issue, the student worker created a new sign with a picture of the beverage cup with a red slash across it. This sign was placed on all three compartments of each bin, and it helped keep the contamination levels of this product low.

To keep the program active and fresh during the second semester, the original educational poster was altered for a new year so that the student body would recognize that the program was ongoing. The second draft of educational posters had the actual items that were served in the dining hall glued on poster board and these were placed above each bin. The new posters explained the composting program process that occurred once students disposed of the materials. This helped educate the students in understanding university students are participating and running the composting operation instead of an outside third party. This also helped educate students on the other items of trash sent to the landfill.

At the onset of the program, the researchers had expected to make daily collection runs of the organic residuals to the composting site. However, researchers realized that the system would be more efficient by collecting twice per week because the material included a lot of paper that kept odors at a minimum. Placing organic residuals inside polyethylene bags where they were debagged at the compost site also allowed for food waste to be held for processing for longer periods of time. The polyethylene bags were returned to the student center's trash compactor to keep costs of waste from the student center accurate.

Pre versus post-waste audits. The pre and post-waste audits results indicated the composting program impacted the amount of waste diverted from the student center to the landfill. 
Table 5. Wilcoxon signed rank test comparing pre-test and post-test weights and percent of total weights of trash collected in waste audits in an economic analysis of a university educational cafeteria-composting program at Texas State University, San Marcos.

\begin{tabular}{|c|c|c|c|}
\hline Category & $\begin{array}{c}\text { Pre-test overall } \\
\text { wt }[1 \mathrm{lb}(\% \text { total })]^{\mathrm{z}}\end{array}$ & $\begin{array}{l}\text { Post-test overall } \\
\text { wt }[1 \mathrm{lb}(\% \text { total })]\end{array}$ & $P$ \\
\hline Liquids & $268(16.08)$ & $165(14.75)$ & \\
\hline Post consumer food waste & $339(20.34)$ & $190(16.98)$ & \\
\hline Food containers & $17(1.02)$ & $19(1.69)$ & \\
\hline Plastic bottles & $43(2.58)$ & $19(1.69)$ & \\
\hline Trash & $223(13.39)$ & $128(11.44)$ & \\
\hline Beverage cups & $140(8.40)$ & $71(6.35)$ & \\
\hline Polystyrene-number 6 & $47(2.82)$ & $38(3.40)$ & \\
\hline Glass & $21(1.26)$ & $14(1.25)$ & \\
\hline Cans & $15(0.90)$ & $14(1.25)$ & \\
\hline Liners & $68(4.08)$ & $41(3.66)$ & \\
\hline Non-recyclable paper & $485(29.11)$ & $312(27.88)$ & \\
\hline Compost & $0(0.00)$ & $79(7.06)$ & \\
\hline Recycle & $0(0.00)$ & $29(2.59)$ & \\
\hline Total & 1,666 & 1,119 & $0.006^{*}$ \\
\hline
\end{tabular}

Table 6. Wilcoxon signed rank test comparing pre-test and post-test volumes and percent of total volumes of trash collected in waste audits in an economic analysis of a university educational cafeteria-composting program at Texas State University, San Marcos.

\begin{tabular}{|c|c|c|c|}
\hline Category & $\begin{array}{c}\text { Pre-test overall vol } \\
{[\text { gal }(\% \text { total })]^{\mathrm{z}}}\end{array}$ & $\begin{array}{c}\text { Post-test overall vol } \\
{[\text { gal }(\% \text { total })]}\end{array}$ & $P$ \\
\hline Liquids & $31(2.64)$ & $20(2.67)$ & \\
\hline Post consumer food waste & $54(4.60)$ & $32(4.27)$ & \\
\hline Food containers & $44(3.75)$ & $32(4.27)$ & \\
\hline Plastic bottles & $88(7.50)$ & $28(3.74)$ & \\
\hline Trash & $252(21.48)$ & $108(14.44)$ & \\
\hline Beverage cups & $176(15.00)$ & $88(11.76)$ & \\
\hline Polystyrene-number6 & $120(10.23)$ & $76(10.16)$ & \\
\hline Glass & $3(0.26)$ & $3(0.40)$ & \\
\hline Cans & $9(0.77)$ & $9(1.20)$ & \\
\hline Liners & $88(7.50)$ & $44(5.88)$ & \\
\hline Non-recyclable paper & $308(26.26)$ & $166(22.19)$ & \\
\hline Compost & $0(0.00)$ & $88(11.76)$ & \\
\hline Recycle & $0(0.00)$ & $54(7.22)$ & \\
\hline Total & 1,173 & 748 & $0.008^{*}$ \\
\hline
\end{tabular}

A Wilcoxon signed rank test compared the mean difference between the total weights of waste collected at the university student center both with and without the eco-station sorting bins on the pre-test waste audit versus the post-test waste audit and found there were significant differences between the weights and volumes of waste collected with the pre-test weights greater than the post-test weights and volumes (Tables 5 and 6).

The post-test waste audit indicated that an average of $79 \mathrm{lb}$ of organic residuals were diverted to composting and $29 \mathrm{lb}$ of recyclable material were diverted to recycling per day after program implementation. This accounted for a diversion rate of $7.06 \%$ for the compostables and $2.59 \%$ for the recyclables by weight (Table 5 ). These diversion rates brought a decrease of $1 \%$ in the trash category from the post-test compared with the pre-test waste audits (Table 5). The difference between the pre versus post-test waste audit food categories was $3.36 \%$ less in the overall weights $(339 \mathrm{lb}$ on the pre-test, $190 \mathrm{lb}$ on the post-test) due to some food residuals being diverted to the compost bin. Another category that had a decrease in the overall percent by weight was non-recyclable paper, which was reduced by $1.23 \%$ per day due to diversion to composting. Liquids were also decreased by $1.33 \%$ of overall weight per day due to being diverted to compostables (Table 5 ).

Because of the heavy nature of liquids, this category by weight represents a substantial part of the waste stream. It is important to divert these liquids to the composting facility because they contribute to the desired moisture content required for composting and they contain high amounts of sugars, a great source of food for the microorganisms. One suggestion to help increase the diversion rates of these liquids is to convert beverage cups to either compostable cups or washable cups. This way the students can place the entire compostable cup into the compost bin or empty the liquids out of a washable cup into the compost bins. This would also eliminate the beverage cup category article from the trash waste stream which represented a large portion by volume and a major contaminant of the operation.

Changing the food containers and polystyrene to compostables or reusable plates would also increase diversion rates to the compost facility. These actions would also increase the cost savings to the university by reducing the waste hauling costs associated with the student center's trash compactor.

The post-test also illustrated the diversion rates for the compostables by volume were greater than by weight at $11.76 \%$, and this was also true for the recyclables at 7.22\% (Table 6$)$. The reason for the increased percentage diversion rates by volume compared with weight is the majority of the compostables were spoiled paper products, which were lightweight, yet bulky. The recyclables were also lightweight (e.g., cans, plastic bottles) and hold a high volume of air, making them bulky. The non-recyclable paper category was decreased by $4.07 \%$, as well as food residuals by $0.33 \%$ due to the diversion of materials to the compost bin (Table 6). Trash was reduced by $7.04 \%(21.48 \%$ to $14.44 \%)$. The total diversion by volume on the posttest was $88 \mathrm{gal}$ for the compost category and $54 \mathrm{gal}$ for the recycle category. 
ECONOMIC DATA Results. The computed cost saving data for the student center's trash compactor costs was $\$ 198.83$ for the 1-year study time period (Table 1 ). It is important to note, even with the $5 \%$ annual increase in rental cost, the composting program maintained a cost savings. Pre-study pull costs showed a total of 19 pulls at a total cost of $\$ 6854.82$. Pull cost during the study period was calculated at 18 pulls for a total cost of $\$ 6494.04$ (Table 1). The composting program helped reduced collections by one total pull during the study time period, which led to cost savings in waste hauling. This reduction in one pull per year was used to estimate the cost for the subsequent years, and showed substantial cost savings totaling $\$ 501.29$ (Table 1). It should be noted that some of the reduction in volume of trash was due to the diversion of recyclables, which were not previously diverted at the student center, as well as compostables targeted by the Bobcat Blend composting program. Since the pilot study included just one building on the overall campus, this savings could be multiplied throughout campus with the addition of more dining halls to the program.

The first year of the composting program had a net loss of $\$ 3741.35$ (Table 2). This loss was mainly due to the additional labor needed to start-up the program and to conduct research by the graduate student coordinator. However, the program shows a net gain of $\$ 2585.11$ for the subsequent years (Table 2). This represents an estimated payback period of less than 2 years for the composting program. It is important to note that not all fixed and initial costs were included in this payback period due to the pre-existing purchase of land and equipment through grants and donations. This net gain represents an estimated cost savings to the university, and this gain is expected to increase as the program matures and expands to other dining halls on campus. An overall cost savings in addition to the savings generated from reduced use of the trash compactor were compared with the overall costs of the program to illustrate the savings/losses from the composting program (Table 3).

\section{Conclusions}

This study found the compost site provided an on-site university laboratory and generated finished compost used for applications in university gardens. Student workers learned skills involving real world problems applicable in the agricultural and/or waste management industry. It was understood that education played a key role in all aspects of the composting program. The more time spent educating students on the purposes and needs of composting and the items that are compostable brought higher diversion rates which, in return, brought higher cost savings.

\section{Literature cited}

Beck, R.W. 2009. Organic Waste Best Management Practices. 1 Jan. 2011. <http:// www.h-gac.com/community/waste/ management/recycling/documents/ organics_waste_best_management_practices_ study.pdf $>$.

Bonhotal, J. and K. Rollo. 1996. Compost Because a Rind is a Terrible Thing to Waste. 14 Aug. 2010. <http://cwmi.css. cornell.edu/compostbecause.pdf>.

Creighton, S.H. 1999. Greening the ivory tower: Improving the environmental track record of universities, colleges, and other institutions. MIT Press, Cambridge, MA.

Dowie, W., D. McCartney, and J. Tamm. 1998. A case study of an institutional solid waste environmental management system. J. Environ. Mgt. 53:137-146.

Goldstein, J. 1993. The backward way to a $\$ 3,000,000$ business. In Business November/December: 32-33

Interlink Media. 2010. Internet Auto Guide. 14 Aug. 2010. <http://www. internetautoguide.com>.

Kantor, L.S., K. Lipton, A. Manchester, and V. Oliveira. 1997. Estimating and addressing America's food losses. Food Rev. 20(1):2-12.

Leal Filho, W., F. MacDermot, and J. Padgam. 1996. Implementing sustainable development at university level - a manual of good practice. Cre-Copernicus Bradford and European Research and Training Centre on Environmental Education, Univ. of Bradford, Bradford, UK.

Mansfield, W.H., III. 1998. Taking the university to task. World Watch 11(3):24-31.

Mohee, R. 2004. Medical wastes characterization in healthcare institutions in Mauritius. Waste Mgt. 25(6):575-581.

Orr, D. 1989. Regeneration of the university. Conserv. Biol. 3:218-219.
Resource Recovery Board Inc. 2010. Waste audit guide. 14 Aug. 2010. <http://www. rrfb.com/pdfs/RRFB_Waste_Audit_Guide. pdf>.

Rynk, R. 1992. On-farm composting handbook. Natural Resource Agr. Eng. Serv., Cornell Univ. Coop. Ext., Ithaca, NY.

Shiralipour, A., D. McConnell, and W. Smith. 1992. Uses and benefits of MSW compost: A review and an assessment. Biomass Bioenergy 3:267-279.

Slivka, D.C., M.A. Thomas, A.R. Buhr, and R. Albrecht. 1992. Compost: United States supply and demand. Biomass Bioenergy 3:281-299.

Texas Commission for Environmental Quality. 2009. Municipal solid waste in Texas-A year in review, FY2008 data and summary analysis. AS-187/09. 13 Dec. 2010. <http://www.tceq.state.tx.us/ assets/public/comm_exec/pubs/as/187_ 09.pdf>.

Tyler, R.W. 1993. The promise of compost. Amer. Nurseryman 180(14):61-73.

Tyler, R.W. 1996. Winning the organics game. ASHS Press, Alexandria, VA.

United Nations. 1987. Our common future: Report of the World Commission on Environment and Development, General Assembly Resolution 42/187 (Brundtland Report). Oxford University Press, United Nations, New York.

U.S. Composting Council. 2002. Test methods for the examination of composting and compost. U.S. Composting Council, Bethesda, MD.

U.S. Environmental Protection Agency. 1993. Markets for compost. EPA 530-SW90-073A. 1 Jan. 2011. <http://www.epa. gov/osw/conserve/rrr/composting/ pubs/bok04.pdf>.

U.S. Environmental Protection Agency. 2010a. Wastes-resource conservationcommon wastes \& materials - organic materials. 24 Mar. 2010. <http://www.epa.gov/ wastes/conserve/materials/organics / index.htm>.

U.S. Environmental Protection Agency. 2010 b. Inventory of U.S. greenhouse gas emissions and sinks: 1990-2008. EPA 430-R-10-006. 14 Aug. 2010. <http:// www.epa.gov/climatechange/emissions/ usgginventory.html>.

U.S. Environmental Protection Agency and U.S. Department of Agriculture. 2011. Waste not, want not: Feeding the hungry and reducing solid waste through food recovery. EPA 530-R-99-040. 1 Jan. 2011. <http://www.epa.gov/osw/conserve/ materials/organics/pubs/wast_not.pdf>. 